LINGUA, Vol. 12, No. 1, Maret 2015

p ISSN: 1979 9411; e ISSN: 2442 238X; Web: lingua.pusatbahasa.or.id Pusat Kajian Bahasa dan Budaya, Surakarta, Indonesia

Solikhah, Imroatus. 2015. KKNI dalam Kurikulum Berbasis Learning Outcomes. Lingua, 12(1): 1 22.

\title{
KKNI DALAM KURIKULUM BERBASIS LEARNING OUTCOMES
}

\author{
Imroatus Solikhah \\ Program Pendidikan Bahasa Inggris \\ IAIN Surakarta \\ Email: iimqueenoslo@gmail.com
}

\begin{abstract}
This article, for all intents and purposes, is to describe the CompetencyBased Curriculum in respons to the advent of National Qualification Framework (KKNI) that sets Outcomes-Based Curriculum in a wide range of education practices. The objectives of the article are to persuit the nature of competency and the learning outcomes delineated in the KKNI clarifying some terms that are still confius. Concepts of curriculum design pertaining to development of needs analyis are briefly discussed. In addition, a substantial discussion on the learning outcomes, core competency, competency, and objectices from where curriculum development is based upon is outlined. In the perspective of Indonesian policy, Competency-Based Curriculum will be no longer implemented as the advent of KKNI would give great impact on the Outcomes-Based Curriculum.
\end{abstract}

Key-words: competency, core competency, learning outcomes, KKNI.

Implementasi kurikulum di Indonesia telah mengalami perubahan mendasar dalam kurun waktu yang tidak lama. Ketika, pelaku pendidikan mulai beradaptasi dan mulai paham dengan substansi satu kurikulum, kebijakan tekah berubah sehingga implementasi kurikulum lebih merupakan "ritual syariat" dibanding implementasi kompetensi kurukulum itu sendiri. Perubahan "ritual" itu kini terjadi seiring dengan perubahan kurikulum 2013.

Perubahan hasil belajar yang sebelumnya diukur menggunakan kompetensi, dan hasil belajarnya disebut standar kompetensi, telah diubah menjadi learning outcomes. Penyesuaian ini berimplikasi pada kurikulum yang sebelumnya disebut dengan Kurikulum Berbasis Kompetensi (KBK) dengan sendirinya disesuaikan menjadi Kurikulum Berbasis Outcomes (KBO). Secara teknis dalam penyusunan silabus, KBK menyebutkan takaran kompetensi dalam bentuk Standar Kompetensi (SK) dan Kompetensi Dasar (KD). Dalam KBO, rujukan utama ialah Kerangka Kualifikasi Nasional yang disebutan dalam Peraturan Presiden No. 8 Tahun 2012 dan dalam praktik penyusunan silabus, diadakan penyesuaian sebutan Kompetensi Inti (KI) dan KD.

Perubahan kerangka kurikulum sebagaimana diuraikan di atas, bersifat sangat substansial sehingga berpengaruh besar terhadap rancangan dan pengembangan kurikulum dan silabus. Artikel ini mencoba membedah permasalahan tersebut dari sudut pandang pengembangan kurikulum dengan menghidangkan komponen-komponen kurikulum dari substansi Curriculum and Instructional Design. 


\section{REDEFINISI KBK}

KBK pertama kali muncul pada 1970an dan secara luas diadopsi dalam program pendidikan dan ESL. Pada 1980an, KBK diterima secara luas dalam program nasional ESL dan pengembangan kurikulum (Auerbach, 1986:411 \& Richards, 2002:128). Pada 1986, emigran di AS direkrut berdasarkan program berbasis kompetensi. Dewasa ini, KBK muncul di berbagai belahan dunia sebagai pendekatan utama dalam perencanaan pembelajaran bahasa.

KBK didefinisikan sebagai program pembelajaran yang diuraikan dengan jelas, konkret, memiliki tujuan yang bisa diukur yang memberi peluang setiap pembelajar yang terlibat dalam proses pembelajaran harus mampu mendemonstrasikan kemampuan seperti yang ditargetkan di akhir program. Depdiknas (2003) menjelaskan KBK ialah kurikulum yang dirancang berdasarkan hasil belajar berupa kompetensi. Kompetensi itu sendiri didefinisikan sebagai kemampuan melakukan pekerjaan berdasarkan pengetahuan, keterampilan dan sikap kerja menurut ukuran atau standar tertentu yaitu SK. Penguasaan ilmunya disebut competence dan kemampuan mendemonstrasikan disebut competency (Auerbach, 1986; Richards, 2013).

KBK yang sudah berjalan sejak 2003 telah melahirkan pemahaman baku tentang kurikulum dan implementasinya. Dampak yang ditimbulkan dengan diberlakukannya KBK cukup luas. Dalam evaluasi kurikulum, dampak tersebut bisa diidentifikasi dari aspek: tujuan pembelajaran, isi, organisasi, metodologi, dan evaluasi hasil belajar.

Tujuan pembelajaran telah ditetapkan secara permanen berupa SK dan KD. Depdiknas (2003) menegaskan, SK dan KD telah dirumuskan sebagai indikator pembelajaran secara nasional, sehingga SK-KD tidak boleh diubah oleh guru. Isi bahan ajar menunjukkan cakupan materi dan uraian bahan yang digunakan untuk mengantarkan topik dan tema. Materi ajar disebut kajian bahan ajar. Dalam istilah baku kurikulum materi disebut sebagai contents (isi) dan menjabarkan materi ajar yang akan disajikan untuk pembelajar. Organisasi menunjukkan pola penyusunan bahan ajar. Metodologi ialah implementasi isi kurikulum dalam proses pembelajaran dan metode mengajar yang sesuai. Evaluasi ialah penilaian kesesuaian antara hasil belajar dengan SK-KD dan isi-metodologi dan hasil belajar (Richards, 2013; Imroatus Solikhah, 2014a).

Implementasi kurikulum di lapangan ternyata tidak sederhana. Di sekolah guru-guru cukup sibuk dengan menyiapkan perangkat pembelajaran, mulai silabus, bahan ajar, dan yang paling rumit, penilaian. Penilaian yang disebut dengan penilaian otentik (authentic assessment) telah menyita banyak waktu dan tenaga untuk mempersiapkannya. Yang justru paling mendasar ialah pengembangan perangkat assesmen otentik, berupa portofolio, rubrik, angket, dokumen, dan wawancara telah cukup melelahkan. Penilaian yang banyak mendasarkan pada "tes esai" atau uraian menyita banyak waktu karena kesulitan merumuskan "item pertanyaan" dan rubrik penilaian dalam bentuk deskripsi indikator dan kuantifikasi skor. Ketika mereka mulai mapan dengan pekerjaannya, kini orientasi dan arah kurikulum telah dibuah.

Di perguruan tinggi, KBK juga telah menimbulkan persoalan sendiri dilihat dari aspek pengelompokkan mata kuliah yang dikatakan oleh Mendiknas (2008) sebagai penyepadanan 
kerangka pendidikan menurut UNESCO. Karena kerangka pikir KBK di pergurun tinggi digunakan secara luas untuk menentukan kualifikasi lembaga, dampaknya juga luas.

Menurut Depdiknas (2010) kurikulum Pendidikan Tinggi telah mengalami perubahan yang semula berbasis isi (content-based curriculum) menjadi KBK. Kurikulum berbasis isi perlu disesuaikan dengan perkembangan kemajuan dan globalisasi. Pembelajaran yang sebelumnya berbasis pokok bahasan dan hasil belajar diukur dengan penguasaan bidang ilmu tertentu, dalam KBK diganti dengan berbasis kinerja atau kompetensi. Pembelajaran berubah menjadi leaners-centered yang mendorong mahasiswa belajar secara humanis-demokratis dan metode mengajar yang mengandalkan ceramah diganti dengan pembelajaran berbasis konteks dengan menggunakan variasi metode kreatif. Periksa bagan 1.

\begin{tabular}{|c|c|c|}
\hline PERSYARATAN & $\begin{array}{c}\text { IBE } \\
\text { UNESCO }\end{array}$ & $\begin{array}{l}\text { KURIKULUM INTI \& } \\
\text { INSTITUSIONAL }\end{array}$ \\
\hline \multirow{2}{*}{$\begin{array}{l}\text { Penguasaan pengetahuan } \\
\text { dan ketrampilan : } \\
\text { - analisis dan sintesis } \\
\text { - menguasai IT/computting } \\
\text { - managed ambiguity } \\
\text { - communication } \\
\text { - } 2 \text { nd language }\end{array}$} & $\begin{array}{l}\text { learning to } \\
\text { know }\end{array}$ & $\begin{array}{c}\text { Matakuliah } \\
\text { Keilmuan dan Ketrampilan } \\
(\text { MKKK) }\end{array}$ \\
\hline & $\begin{array}{l}\text { learning to } \\
\text { do }\end{array}$ & $\begin{array}{c}\text { Matakuliah } \\
\text { Keahlian Berkarya } \\
(\text { MKKB ) }\end{array}$ \\
\hline $\begin{array}{l}\text { Attitude : } \\
\text { - kepemimpinan } \\
\text { - teamworking } \\
\text { - can work crossculturally }\end{array}$ & $\begin{array}{c}\text { learning to } \\
\text { be }\end{array}$ & $\begin{array}{c}\text { Mata kuliah } \\
\text { Perilaku Berkarya } \\
(\text { MKPB ) }\end{array}$ \\
\hline \multirow[t]{2}{*}{$\begin{array}{l}\text { Pengenalan sifat pekerjaan } \\
\text { terkait : } \\
\text { - Terlatih dalam etika kerja } \\
\text { - Memahami makna globalisasi } \\
\text { - Fleksibel thd pilihan pekerjaan }\end{array}$} & $\begin{array}{l}\text { learning to } \\
\text { live together }\end{array}$ & $\begin{array}{c}\text { Mata kuliah } \\
\text { berkehidupan bersama } \\
(\text { MKBB ) }\end{array}$ \\
\hline & & $\begin{array}{c}\text { MK Pengemb. Kepribadian } \\
\text { (MKPK) }\end{array}$ \\
\hline
\end{tabular}

Bagan 1. Penyepadanan KBK dan Pilar Pendidikan UNESCO.

Kompetensi dalam KBK perguruan tinggi terdiri dari kompetensi utama, kompetensi pendukung, dan kompetensi lain. Dalam Kepmendiknas No. 045/U/2002, kompetensi didefinisikan sebagai seperangkat tindakan cerdas, penuh tanggungjawab yang dimiliki seseorang sebagai syarat untuk dianggap mampu oleh masyarakat dalam melaksanakan tugastugas di bidang pekerjaan tertentu (Pasal 1). Kompetensi tersebut terdiri atas: (1) kompetensi utama, (2) kompetensi pendukung, (3) kompetensi lain yang bersifat khusus dan gayut dengan kompetensi utama (Pasal 2). Dalam struktur kurikulum prodi, kompetensi utama mewarnai Kurikulum Inti. Sedangkan, kompetensi pendukung dan kompetensi lain dapat dituangkan dalam Kurikulum Institusional/Lembaga. Implikasinya, setiap MK harus ditetapkan 
kompetensi standar yang menjadi acuan (standard competencies) dan kompetensi dasar (basic competencies).

Kompetensi Utama ialah kemampuan minimal untuk menampilkan unjuk kerja yang memuaskan sesuai dengan penciri program studi. Kompetensi Pendukung merupakan kemampuan yang gayut dan dapat mendukung kompetensi utama serta merupakan ciri khas PT yang bersangkutan. Kompetensi lain ialah kKemampuan yang ditambahkan yang dapat membantu meningkatkan kualitas hidup, dan ditetapkan berdasarkan keadaan serta kebutuhan lingkungan PT.

Tujuan dan arah pendidikan tinggi didasarkan pada lima pilar pendidikan yang dikembangkan dari pilar UNESCO (Keputusan Mendiknas No. 232/U/2000). Kelima pilar tersebut adalah: (1) Mata Kuliah Pengembangan Kepribadian (MPK), (2) Mata Kuliah Keilmuan dan Keterampilan (MKK), (3) Mata Kuliah Keahlian Berkarya (MKB), (4) Mata Kuliah Perilaku Berkarya (MPB), dan (5) Mata Kuliah Berkehidupan Bermasyarakat (MBB). Berdasarkan pilar dikebangkan Kurikulum Inti dan elemen-elemen kompetensi yang harus dikembangkan dalam KI suatu program studi (Kepmendiknas No. 045/U/2002). Periksa bagan 2 .

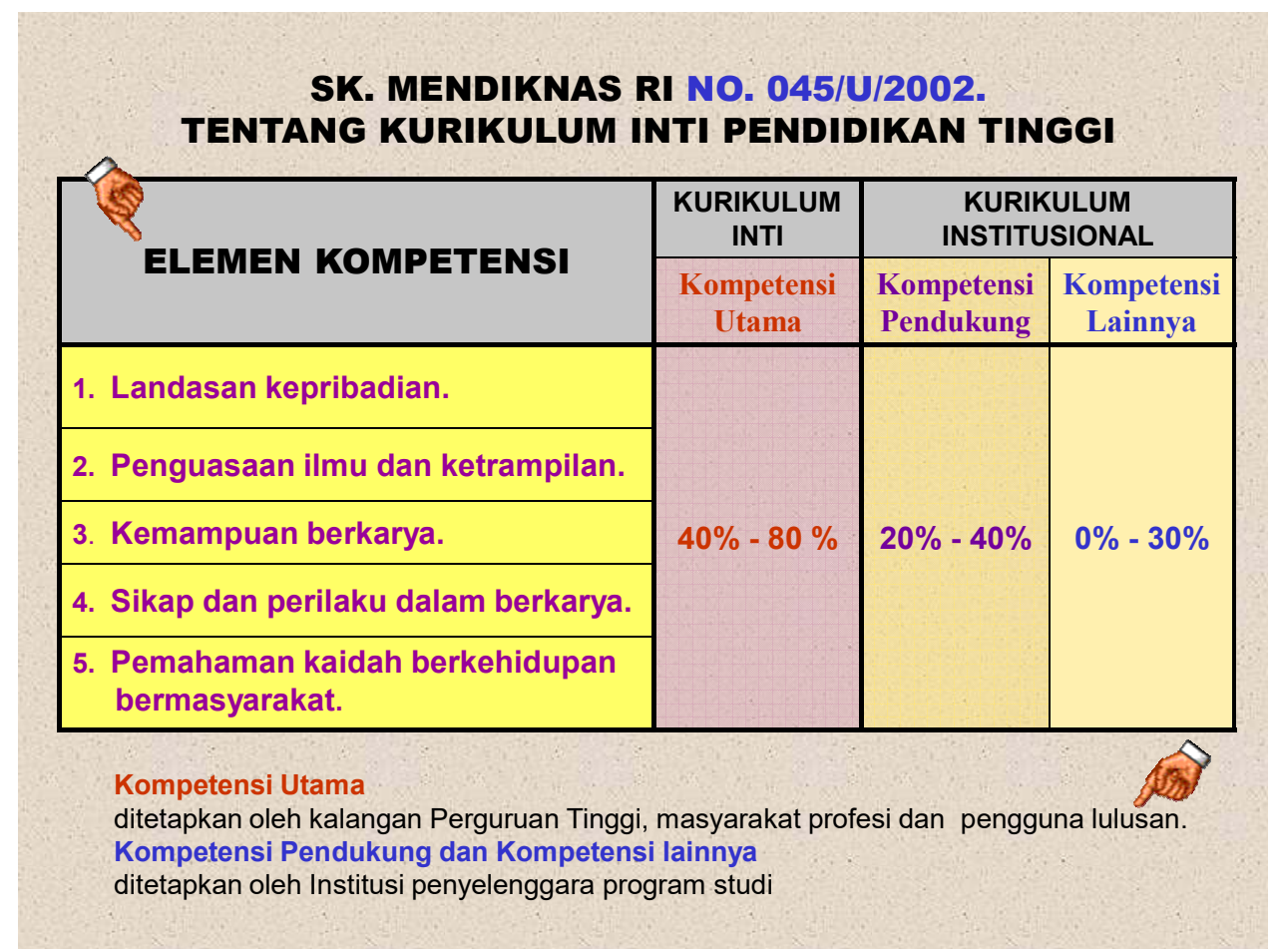

Bagan 2. Proporsi Elemen Kompetensi dalam KBK.

\section{KURIKULUM BERBASIS LEARNING OUTCOMES}

Kerangka Kualifikasi Nasional Indonesia disingkat KKNI ialah acuan penjenjangan kualifikasi kompetensi untuk pengakuan kerja. KKNI telah dirumuskan oleh Mendikbud 
pada 2010 sebagai acuan pengembangan kurikulum. KKNI kemudian diundangkan melalui Peraturan Presiden Nomor 8 Tahun 2012 tentang Kerangka Kualifikasi Nasional Indonesia.

Kehadiran KKNI sebenarnya merupakan acuan umum bagaimana kualifikasi seseorang mendapat pengakuan di dunia kerja. Mendikbud (2010:4) menjelaskan: kebutuhan Indonesia untuk segera memiliki KKNI sudah sangat mendesak mengingat tantangan dan persaingan global pasar tenaga kerja nasional maupun internasional semakin terbuka. Pergerakan tenaga kerja dari dan ke Indonesia tidak lagi dapat dibendung dengan peraturan atau regulasi yang bersifat protektif.

Agar dalam jangka pendek dan jangka panjang Indonesia mampu bertahan tetapi tetap bergerak maju di arena ekonomi global, maka pengakuan timbal balik dan setara dengan negara asing menjadi butir-butir yang kritis dalam pengembangan suatu kerangka kualifikasi tenaga kerja nasional (Mendikbud, 2010:4). KKNI merupakan penjenjangan kualifikasi kompetensi yang dapat menyandingkan, menyetarakan, dan mengintegrasikan antara bidang pendidikan dan bidang pelatihan kerja sesuai dengan struktur pekerjaan di berbagai sektor (Perpres No. 8 Tahun 2012 Pasal 1 Ayat (1)).

Ada tiga strategi pengembangan KKNI. Pertama, KKNI menganut strategi kesetaraan kualifikasi seseorang yang diperoleh dari dunia pendidikan formal, nonformal, informal dan pengalaman bekerja. Kedua, KKNI mengakui kualifikasi pemegang ijazah yang akan bekerja maupun melanjutkan pendidikan di luar negeri, pertukaran pakar dan mahasiswa lintas negara atau pemegang ijazah dar luar negeri yang bekerja di Indonesia. Ketiga, KKNI mengakui kesetaraan kualifikasi capaian pembelajaran berbagai bidang keilmuan pada tingkat pendidikan tinggi, baik yang berada pada jalur pendidikan akademik, vokasi, profesi, serta melalui pengembangan karir yang terjadi di strata kerja, industri atau asosiasi profesi (Mendikbud, 2010:11).

KKNI terdiri dari 9 jenjang kualifikasi. Deskripsi jenjang kualifikasi KKNI menurut Perpres No. 8 Tahun 2012 diuraikan dalam bagan 3.

1) Jenjang 1 sampai 3 dikelompokkan dalam jabatan operator diduduki lulusan SD, SMP dan SMA.

2) Jenjang 4 sampai 6 dikelompokkan dalam jabatan teknisi atau analis, diduduki oleh lulusan D1, D2, D3, D4 dan Sarjana.

3) Jenjang 7 dikelompokkan dalam jabatan ahli, diduduki oleh lulusan pendidikan profesi.

4) Jenjang 8 dikelompokkan dalam jabatan ahli diduduki oleh lulusan magister atau spesialis 1 .

5) Jenjang 9 dikelompokkan dalam jabatan ahli diduduki oleh lulusan doktor atau spesialis 2 . 


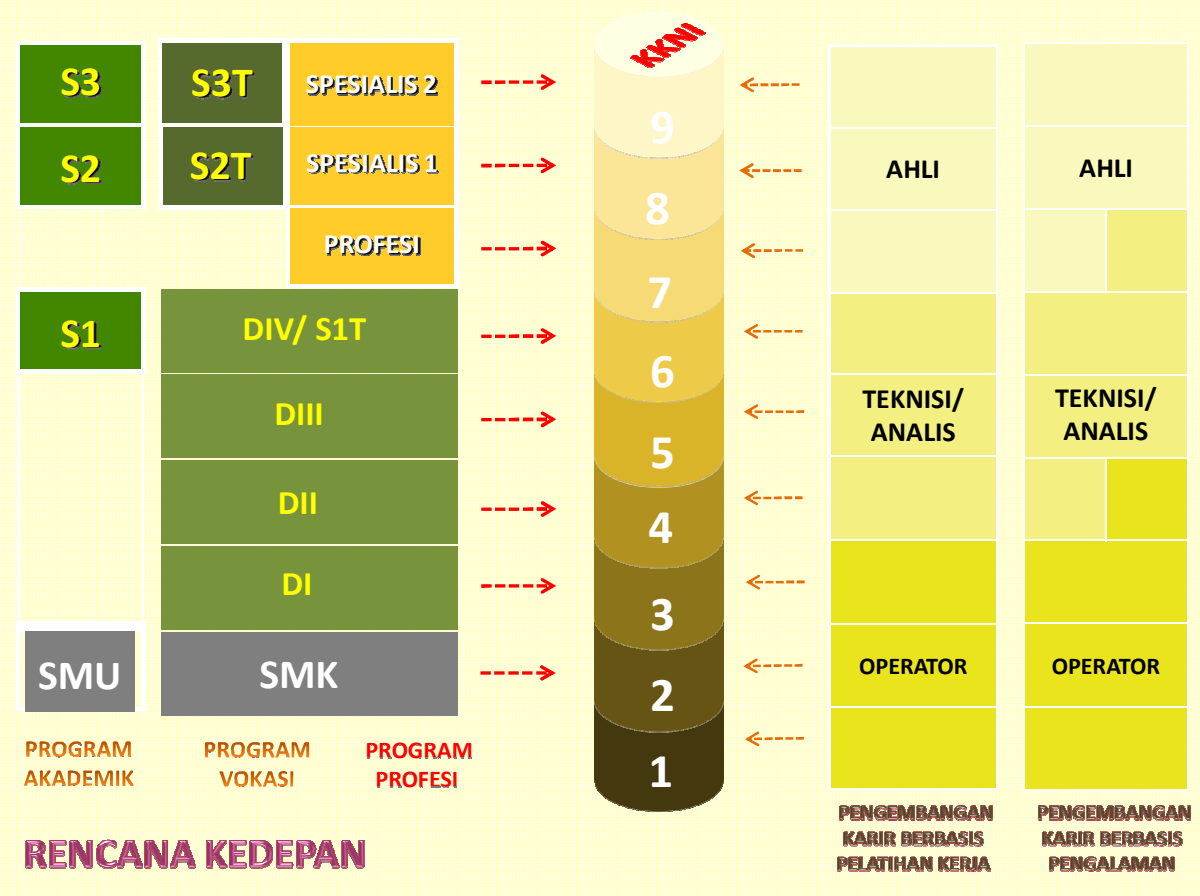

Bagan 3. Deskripsi KKNI Menurut Perpres No. 8 Tahun 2012

Secara konseptual, setiap jenjang kualifikasi dalam KKNI disusun oleh empat parameter, yaitu: (1) keterampilan kerja, (2) cakupan keilmuan (pengetahuan), (3) metode dan tingkat kemampuan mengaplikasikan keilmuan, dan (4) kemampuan manajerial (Mendikbud, 2010:18). Internalisasi dan akumulasi keempat parameter yang harus dicapai melalui proses pendidikan yang terstruktur atau melalui pengalaman kerja disebut dengan learning outcomes atau capaian pembelajatan (Mendikbud, 2010:19).

\section{PROSES PENGEMBANGAN KBK DAN KBO}

Jika dicermati, antara KBK dan KBO terdapat kesamaan dan perbedaan. Kesamaannya, KBK dan KBO keduanya melihat hasil belajar dengan ukuran yang disebut kompetensi. Hasil belajar itu memiliki tiga sebutan yang mirip, yaitu: kompetensi (competency), capaian hasil dan learning outcomes (Depdiknas, 2010). Perbedaannya, KBK menganggap kompetensi merupakan takaran keberhasilan akhir, sedangkan KBO mempersyaratkan kompetensi yang dicapai harus dikaitkan dengan ketercapaiannya di masyarakat, dunia kerja, dan kesetaraan dengan kualifikasi tertentu. Kompetensi ini disebut dengan learning outcomes.

Dari aspek pengembangan kurikulum, sebenarnya proses pengembangan KBK dan KBO kurang lebih sama. Richards (2013) dan Lawerence (2013) menjelaskan KBK dimulai dari analisis kebutuhan untuk menentukan learning outcomes dan objectives. KBK dimulai dengan spesifikasi hasil belajar dalam bentuk kompetensi. Kompetensi sendiri didefinisikan 
sebagai pengetahuan, keterampilan dan perilaku siswa yang tampak pada tugas dan aktivitas sehari-hari yang harus dikuasai siswa di akhir program pembelajaran.

Needs analysis dilakukan melalui lima langkah (Richards, 2013:23), yaitu: (1) Mengidentifikasi kebutuhan komunikatif pembelajar, (2) Membuat pernyataan mengenai tujuan belajar, (3) Mengidentifikasi isi bahasa dan keterampilan berbahasa sesuai dengan tujuan, (4) Mempersiapkan perencanaan course, dan (5) Memilih materi dan metode mengajar. Richards (2013) juga telah mendeskripsikan proses perumusan KBK ke dalam enam hal dan divisualisasikan dalam bagan 4. Keenam hal itu ialah: (1) Needs analysis, (2) Mengidentifikasi topik dalam kurikulum, misalnya: perbankan, belanja, kesehatan, (3) Mengidentifikasi kompetensi untuk setiap topik, (4) Mengelompokkan kompetensi dalam unit-unit pembelajaran, (5) Mengidentifikasi pengetahuan bahasa dan skill yang diperlukan untuk setiap unit pembelajaran, misalnya 4 skills, vocabulary, grammar dan (6) Memilih bahan ajar.

\section{PENAJAMAN ISTILAH DALAM KBO}

Implementasi KKNI menimbulkan mermasalahan dalam design kurikulum dan pembelajaran di setiap jenjang pendidikan. Terjadi penafsiran, seolah-olah KKNI ialah pengganti KBK. KKNI mengacu pada Kurikulum Berbasis Outcomes.

Yang sebenarnya terjadi ialah KKNI ialah rujukan dalam menetapkan hasil belajar. Secara otomatis design kurikulum juga harus berubah, terutama dalam rumusan hasil belajar dan tujuan pembelajaran. Pemerintah sendiri mengakui, terdapat tiga istilah yang memiliki makna hampir sama dalam KKNI tetapi hakikatnya berbeda: kompetensi, capaian hasil, dan learning outcomes (Mendikbud, 2010).

\section{Learning Outcomes}

Dalam KBO hasil belajar diukur bukan berdasarkan tujuan pembelajaran tetapi learning outcomes (LO). LO menunjukkan apa yang sebenarnya dipelajari oleh pembelajar. LO terdiri dari tiga level: outcomes umum, outcomes program, dan outcomes mata kuliah (Palm Beach State College, 2013). LO ialah skill dan pengetahuan yang harus dikuasai pembelajar setelah program selesai. Jadi, LO merupakan pernyataan apa yang harus dicapai pembelajar setelah mengikuti program pembelajaran (Manual of Queen Mary University of London, 2013). LO didasarkan pada kebutuhan pembelajar, kebutuhan masyarakat, dan apa yang harus diketahui pembelajar mengenai subjek tertentu (Learning Management Corporation, 2013, www.thelearningmanagement.com).

LO yang baik harus terkait dengan tujuan program, merujuk pada kriteria eksternal, dan jelas untuk staf, pembelajar, dan penguji eksternal (Queen Mary University of London, 2013). LO harus berpusat pada pembelajar, spesifik, dan bisa diukur atau diamati. Salah satu teknik menyusun LO ialah menggunakan rumus A-B-C-D (Palm Beach State College, 2013:8), Audience, Behavior, Condition, Degree. Contoh: 
The students

will apply appropriate techniques for addressing a policy decision problem

When givenone,

$90 \%$ of the time

Given a policy decision problem,

the students

Will apply appropriate techniques for addressing it

$90 \%$ of the time
Audience
Bahavior
Condiiton
Degree

\section{Condition \\ Audience \\ Behavior \\ Degree}

Untuk menyusun LO, perlu dihindari penggunaan kata-kata atau ekspresi kurang jelas dan tidak bisa diukur, misalnya: "mengetahui, memahami, menghargai, belajar, mengenal". Kata-kata yang dianjurkan ialah: "menunjukkan, menjelaskan, mendefinisikan, mendeskripsikan, memprediksi, mengidentifikasi."

LO terdiri dari: (1) Knowledge-based: pengetahuan dan pemahaman; menjabarkan pengetahuan yang harus dicapai pembelajar, (2) Application-based: keterampilan praktis; menjelaskan jenis aplikasi atau transformasi yang harus diperoleh mahasiswa, dan (3) Skillsbased: keterampilan intelektual dan transfer; pengembangan keterampilan dan penguasaan pengetahuan (Queen Mary University of London, 2013:11). LO ditulis dengan mempertimbangkan (1) Menggunakan "future tense": "By the end of this module ... Students will be able to...", (2) Hindari menulis LO untuk menggantikan silabus, (3) Pastikan LO bisa dicapai dan diukur, (4) Gunakan bahasa dan kata yang bisa dimengerti mahasiswa, (5) Menjelaskan proses dan hasil. Misalnya, "Bisa merencanakan dan mengimplementasikan suatu proyek penelitian", (5) Sesuai dengan level mata kuliah, dan (6) Disusun secara berimbang dalam outcomes yang berbeda-beda.

Pernyataan LO bisa dielaborasi ke dalam tiga komponen: (1) kata kerja operasional (action words) menunjukkan kinerja, (2) pernyataan belajar (learning statement) yang menunjukkan secara spesifik belajar apa yang harus ditunjukkan dalam kinerja, dan (3) pernyataan umum mengenai kriteria atau standar kinerja.

Contoh aim, objective dan learning outcomes

\section{Aims}

Reading-To develop reading skill in three levels of comprehension

\section{Objective}

To demonstrate the skills in literal, inferential, and critical comprehension on the passage of 3,000 word and academic vocabulary

\section{Learning outcome}

Students should be able to demonstrate reading skills of a text 3.000 words and academic vocabulary.

LO memiliki tiga kelemahan. Pertama, outcomes-based approach tidak memberi ruang untuk mengembangkan kreativitas. Hal ini terjadi jika LO dirumuskan terlalu sempit atau jika LO hanya merupakan satu-satunya rumusan hasil belajar. Akibatnya, LO tidak bisa mendorong proses belajar. Kedua, untuk pembelajaran di perguruan tinggi, LO bisa disamakan dengan proses "menyuapi" (spoon-feeding) dan mahasiswa bisa menganggap semua yang dipelajari sudah tertuang seluruhnya di dalam LO. Hal ini terjadi jika LO ditulis 
menurut pandangan lembaga, bukan membantu mahasiswa memahami apa yang harus dicapai. LO bukan pengganti silabus yang rinci dan juga bukan petunjuk penilaian hasil belajar. Ketiga, LO sering dibuat oleh staf administrasi yang lebih banyak menguasai aspek mekanik penulisan silabus dibanding substansinya. LO harus diposisikan sebagai bagian dari modul yang harus dijelaskan pada mahasiswa bersamaan dengan proses belajar. LO bukanlah rumusan setiap apa yang harus diketahui mahasiswa, tetapi pernyataan singkat tentang apa yang harus dicapai mahasiswa (Queen Mary University of London, 2013:8).

\section{Aims dan Objectives}

Aims, goals, dan objectives ketiganya memiliki makna umum tujuan, tetapi dalam istilah kurikulum masing-masing didefinisikan secara berbeda. Richards $(2002 ; 2013)$ mendefinisikan aims dan goals sebagai tujuan umum kurikulum. Keduanya memiliki makna yang sama. Aims banyak digunakan di UK dan goals banyak digunakan di Amerika. Richards (2013) sendiri lebih memilih kata aims untuk menunjukkan tujuan umum kurikulum. Aims dan goals dalam literatur di Indonesia disepadankan dengan TIU dan objectives sama dengan TIK. Peneliti sendiri mengikuti pendapat Richards (2013) dan menggunakan istilah aims untuk TIU dan objectives TIK.

Manual dalam Kurikulum The Learning Institute (2013) dan Queen Mary University of London (2013) menjelaskan aims ialah tujuan umum atau goals dan merupakan pernyataan umum dari guru atau sekolah pada saat merumuskan suatu mata kuliah. Aims bukan pernyataan mengenai apa yang akan dipelajari atau dilakukan pembelajar, tetapi tujuan pelaksanaan suatu mata kuliah atau pelajaran. Aims berusaha menjawab dua pertanyaan: (1) Apakah tujuan dari program atau modul? dan (2) Apa yang akan dicapai dari program atau modul tersebut? Aims dirumuskan secara singkat, jelas dan memberi ide rasional bagi pembelajar mengenai apa yang diharapkan dari mempelajari mata kuliah tertentu.

Arreola (2013) menjelaskan, satu aim bisa memiliki beberapa tujuan pembelajaran yang lebih spesifik. Learning objectives ialah pernyataan apa yang akan bisa dilakukan pembelajar ketika mereka sudah menyelesaikan program. Learning objectives memiliki tiga komponen pokok: (1) Deskripsi apa yang akan bisa dilakukan pembelajar, (2) Kondisi dalam situasi apa pembelajar akan menampilkan kemampuannya, dan (3) Kriteria untuk mengevaluasi kinerja pembelajar. Selain itu, learning objectives merupakan panduan utuk: (1) Menyeleksi isi materi ajar, (2) Pengembangan strategi pembelajaran, (3) Pengembangan dan seleksi materi pembelajaran, dan (4) Penyusunan tes dan instrumen lain untuk menilai dan mengevaluasi learning outcomes (Arreola, 2013:2).

Objectives menjabarkan LO dan merupakan tahapan bagaimana langkah-langkah mencapai kompetensi yang harus dilakukan pembelajar. Objectives yang baik disusun menggunakan pilihan kata yang cermat. Langkah-langkah untuk mencapai outcome menurut The Learning Management Corporation (2013) meliputi:

1) Mendefinisikan outcomes yang spesifik atau kompetensi yang akan dicapai dalam bentuk keterampilan, penguasaan materi, sikap atau nilai.

2) Menemukan dasar pemikiran memilih atau mendesain materi pembelajaran, isi, dan teknik

3) Memberi pedoman menentukan atau menilai kapan tujuan pembelajaran dicapai. 
4) Memberi kerangka pikir bagaimana pembelajar mengorganisasikan usahanya untuk menyelesaikan tugas-tugas belajar.

Contoh berikut, dikutip dari Petunjuk Penulisan Tujuan Pembelajaran di Universitas Tennessee, Memphis (Arreola \& Lawrence, 1998):
Aim/goal
The aim of the Learning Assessment course is to enable the students to make reliable and accurate assessment of learning.
Objective 1
Given a learning objective the student will be able to develop an approppriate multiple-choice question to measure students achievement of the objective.
Objective 2
Given a printout from an item analysis of a multiple-choice exam the student will be able to state accuracy of the test scores.
Objective 3
Given the discrimination and difficulty indices of an item the student will be able to determine if the item contributes to the reliability of the exam

Arreola (2013) menyatakan ada tiga karakteristik penting untuk memastikan agar statemen dalam tujuan pembelajaran menjadi jelas, yaitu:

\section{Behavior.}

1) Tujuan harus mendeskripsikan kompetensi yang dipelajari dalam pernyataan kinerja. Di sini diperlukan penggunaan pilihan kata kerja operasional yang cocok. Kata-kata seperti: mengetahui, memahami, memperoleh, menghargai tidak sesuai untuk digunakan.

2) Kata kerja untuk menyatakan tujuan harus bisa mengidentifikasi perilaku pembelajar yang bisa diamati, kemudian ditetapkan pernyataan tujuan pembelajaran menggunakan kata kerja operasional tersebut.

3) Jenis dan level belajar harus diidentifikasi. Jenis dan level belajar merujuk pada taksonomi hasil belajar dari Bloom. Jenis tujuan menurut Bloom terdiri dari ranah kognitif (keterampilan berpikir atau kemampuan intelektual), psikomotor (keterampilan fisik atau kinerja), dan ranah afektif (sikap dan nilai). Level berpikir meliputi: mengingat, memahami, menerapkan, analisis, sintesis, dan evaluasi.

\section{Criterion.}

1) Objectives harus menjelaskan bagaimana kualitas kinerja yang harus ditampilkan pembelajar setelah selesai mengikuti program.

2) Kualitas kinerja dinyatakan menggunakan pernyataan yang menunjukkan tingkat akurasi, jumlah, atau proporsi respon yang benar yang dikuasai pembelajar.

\section{Condition.}

1) Objectives harus mendeskripsikan kondisi saat pembelajar menunjukkan kinerja pada saat dievaluasi.

2) Alat evaluasi, referensi atau alat bantu yang lain yang akan digunakan atau tidak digunakan harus dinyatakan dengan jelas. 
LINGUA, Vol. 12, No. 1, Maret 2015

p ISSN: 1979 9411; e ISSN: 2442 238X; Web: lingua.pusatbahasa.or.id

Pusat Kajian Bahasa dan Budaya, Surakarta, Indonesia

Solikhah, Imroatus. 2015. KKNI dalam Kurikulum Berbasis Learning Outcomes.

Lingua, 12(1): 1 22.

Contoh rumusan analisis kebutuhan, learning outcomes dan objectives untuk mata kuliah English for Academic Purposes dikutip dari disertasi Imroatus Solikhah (2014a; 2014b) Tabel 1, Tabel 2 dan Tabel 3.

Tabel 1. Analisis Kebutuhan EAP

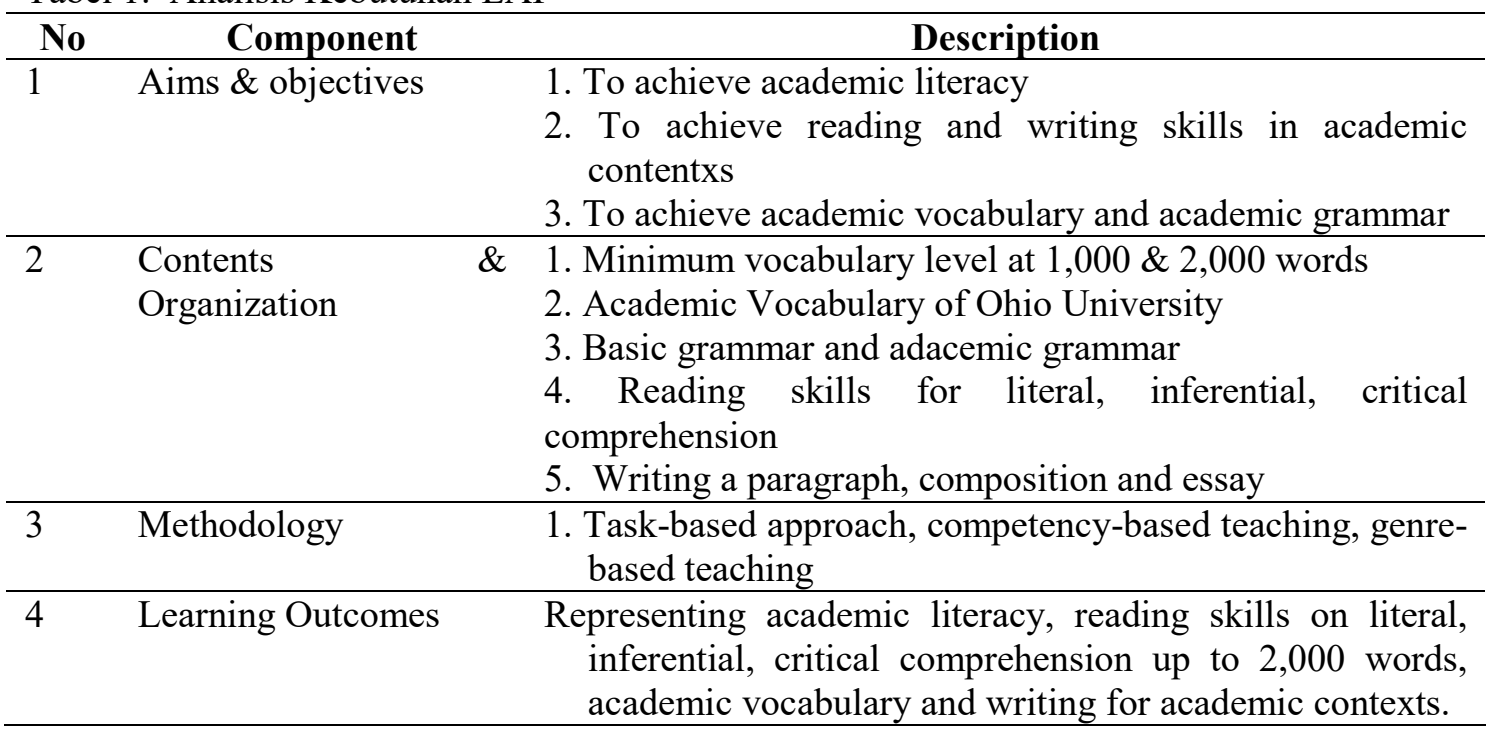

\section{Kompetensi Inti}

Kompetensi Inti (KI) dalam bahasa Inggris ialah core competency. Secara umum, ada tiga jenis kompetensi, yaitu: kompetensi inti (core), kompetensi fungsional (functional), dan kompetensi tugas (task). KI ialah pengetahuan, keterampilan, dan sikap yang harus dimiliki oleh setiap orang. KI memiliki akar mendalam dalam visi dan misi suatu lembaga. Kompetensi fungsional ialah kompetensi yang melekat pada suatu jenis departemen atau lembaga. Kompetensi tugas yaitu kompetensi yang menunjukkan derajat kualitas suatu produk pekerjaan. KI dikembangkan dari analisis kebutuhan pekerjaan dari suatu perusahaan. KI memiliki tiga ranah termasuk aspek kepemimpinan. KI terdiri dari: (1) kompetensi terkait dengan orang lain, (2) kompetensi terkait dengan bisnis, (3) kompetensi terkait dengan manajemen. Inilah nampaknya di dalam KKNI disebutkan dalam jenjang kualifikasi terdapat kemampuan leardership. Periksa Tabel 4 dan KKNI pada Lampiran sebagai perbandingan.

KI tidak sama dengan SK. Jika SK pada KTSP diajarkan kepada siswa, kompetensi inti bukan untuk diajarkan, melainkan untuk dibentuk melalui pembelajaran mata pelajaranmata pelajaran yang relevan. Setiap mata pelajaran harus tunduk pada kompetensi inti yang telah dirumuskan. Semua mata pelajaran yang diajarkan dan dipelajari pada kelas tersebut harus berkontribusi terhadap pembentukan KI.

KI berfungsi sebagai unsur pengorganisasi (organising element) kompetensi dasar. Sebagai unsur pengorganisasi, KI merupakan pengikat untuk organisasi vertikal dan organisasi horizontal KD. Organisasi vertikal KD adalah keterkaitan antara konten KD satu kelas atau jenjang pendidikan ke kelas/jenjang di atasnya. Organisasi horizontal adalah 
keterkaitan antara konten KD satu mata pelajaran dengan konten KD dari mata pelajaran yang berbeda. KI terdiri dari empat kelompok:

1) Sikap keagamaan (KI-1)

2) Sikap social, kepribadian, akhlak (KI-2)

3) Pengetahuan (KI-3)

4) Penerapan pengetahuan (KI-4). Periksa Bagan 4.

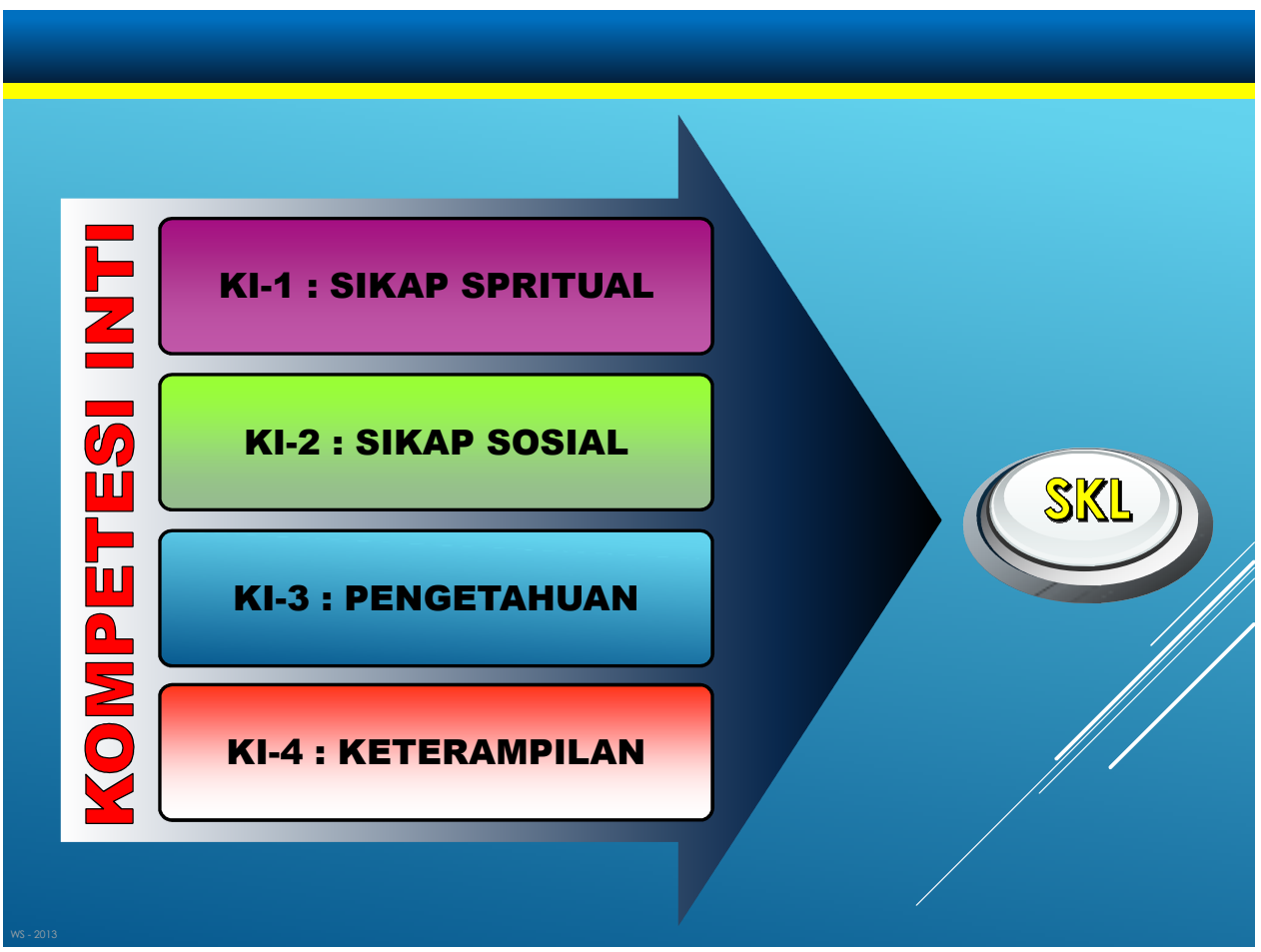

Bagan 3. Struktur Kompetensi Inti

Tabel 2. Kurikulum EAP

\section{Aims}

1. To achieve competency on basic academic literacy in reading and writing

\section{Sources: English for Academic}

Purposes: A CompetencyBased Textbook for EFL

Learners, by Imroatus Solikhah (2014), Penerbit Imperium Yogjakarta.

\section{Objectives}

1. To increase basic knowledge on academic vocabulary

2. To increase mastery on grammar knowledge and academic grammar in context

3. To develop reading skills in literal, inferential, and critical comprehension

4. To develop skills in academic writing from paragraph to essay and Test of Written English essay 
LINGUA, Vol. 12, No. 1, Maret 2015

p ISSN: 1979 9411; e ISSN: 2442 238X; Web: lingua.pusatbahasa.or.id Pusat Kajian Bahasa dan Budaya, Surakarta, Indonesia

Solikhah, Imroatus. 2015. KKNI dalam Kurikulum Berbasis Learning Outcomes. Lingua, 12(1): 1 22.

Tabel 3. Contents and Learning Outcomes of EAP

\begin{tabular}{|c|c|c|c|}
\hline No & Contents & Learning Outcomes & Indicative Contents \\
\hline 1 & $\begin{array}{l}\text { Vocabulary } \\
\text { knowledge, } \\
\text { general and } \\
\text { academic } \\
\text { vocabulary }\end{array}$ & $\begin{array}{l}\text { 1. Identify, implement, and } \\
\text { use of } 1.000 \text { to } 2.000 \\
\text { general words } \\
\text { 2. Identify, compare and } \\
\text { use academic } \\
\text { vocabulary }\end{array}$ & $\begin{array}{l}\text { 1. General words list first- } \\
\text { hundreds to tenth hundreds } \\
\text { 2. General words list of } 2,000 \\
\text { words } \\
\text { 3. Head words, synonym, } \\
\text { antonyms, definition, words } \\
\text { classes, affixes, bound, free } \\
\text { morphemes } \\
\text { 4. Academic words list of Ohio } \\
\text { University }\end{array}$ \\
\hline 2 & $\begin{array}{l}\text { Basic grammar and } \\
\text { academic grammar } \\
\text { from textbook }\end{array}$ & $\begin{array}{l}\text { 1. Identify and use of basic } \\
\text { rules of grammar } \\
\text { 2dentity and use of } \\
\text { typical academic } \\
\text { grammar obtained } \\
\text { from authentic texts, } \\
\text { e.g. textbook chapter, } \\
\text { journals }\end{array}$ & $\begin{array}{l}\text { 1. Basic grammar: to be, tenses, } \\
\text { agreements, sentences, gerund, } \\
\text { passive voices } \\
\text { 2. Sentences: simple, compound, } \\
\text { complex, compound-complex } \\
\text { sentences } \\
\text { 3. Clause and adjective clause } \\
\text { 4. Analysis to grammar in English } \\
\text { textbooks }\end{array}$ \\
\hline 3 & $\begin{array}{l}\text { Reading } \\
\text { comprehension }\end{array}$ & $\begin{array}{l}\text { 1. Identify and use of } \\
\text { reading text of } 1,000 \\
\text { and } 2,000 \text { passages } \\
\text { 2. Implement skills in } \\
\text { various level of } \\
\text { comprehension: literal, } \\
\text { inferential, critical } \\
\text { 3. Identify passages of } \\
\text { academic texts }\end{array}$ & $\begin{array}{l}\text { 1. Comprehension of reading texts } \\
\text { in a range of } 1,000 \text { to } 3,000 \\
\text { words } \\
\text { 2. Comprehension on reading of } \\
\text { authentic text, e.g. TOEFL, } \\
\text { TOEIC, textbook } \\
\text { 3. Competency on the use of } \\
\text { literal, inferential, critical } \\
\text { reading skills }\end{array}$ \\
\hline 4 & $\begin{array}{l}\text { Writing in the } \\
\text { academic context }\end{array}$ & $\begin{array}{l}\text { 1. Develop an academic } \\
\text { paragraph in various } \\
\text { developing details } \\
\text { techniques } \\
\text { 2. Develop three- } \\
\text { paragraph essay and } \\
\text { Test of Written English } \\
\text { (TWE) }\end{array}$ & $\begin{array}{l}\text { 1. Paragraph organization: } \\
\text { opening, the body, conclusion. } \\
\text { 2. Topic sentence, developing } \\
\text { sentences, concluding sentence. } \\
\text { 3. Thesis statement, introductory } \\
\text { paragraph, developing } \\
\text { paragraphs, concluding } \\
\text { paragraph } \\
\text { 4. Expository and argumentative } \\
\text { essay for TWE }\end{array}$ \\
\hline
\end{tabular}

Keempat kelompok itu menjadi acuan dari KD dan harus dikembangkan dalam setiap peristiwa pembelajaran secara integratif. Kompetensi yang berkenaan dengan sikap keagamaan dan sosial dikembangkan secara tidak langsung (indirect teaching) pada waktu peserta didik belajar tentang pengetahuan dan penerapan pengetahuan. 
KI bukanlah pengganti SK. KI berlaku untuk semua bidang studi dan berlaku sama untu setiap bidang pelajaran. KI merupakan terjemahan atau operasionalisasi Standar Kompetensi Lulusan (SKL). KI menjadi acuan dalam perumusan KD. KD didefinisikan sebagai kemampuan untuk mencapai KI yang harus diperoleh peserta didik melalui pembelajaran. Format silabus yang sesuai memiliki urutan: (1) Kompetensi inti, (2) Kompetensi dasar, (3) Materi pembelajaran, (4) Kegiatan pembelajaran, (5) Penilaian, (6) Alokasi waktu, dan (7) Sumber belajar.

Jika dikaji lebih mendalam, secara substansial KI sama dengan core competency yang digunakan dalam kurikulum di berbagai negara maju. Core competency menjadi rujukan untuk menentukan learning outcomes dan learning objectives. Selain itu, ada satu lagi aspek yang menyertai setiap perilaku belajar yaitu yang disebut dengan soft skills.

Schulz (2008) menguraikan perbedaan antara soft skill dan hard skills dengan contohnya sebagaimana diuraikan berikut ini. Soft skill berbeda dengan hard skills. Soft skills bersifat subjektif dan bisa bersifat benar atau tidak benar. Soft skill sering diasosiasikan dengan atribut kepribadian atau karakter.

Tabel 4. Deskripsi Kompetensi Inti dalam Perusahaan

\begin{tabular}{llll}
\hline No & $\begin{array}{l}\text { Kompetensi Terkait } \\
\text { Orang Lain }\end{array}$ & $\begin{array}{l}\text { Kompetensi terkait } \\
\text { dengan Bisnis }\end{array}$ & $\begin{array}{l}\text { Kompetensi terkait } \\
\text { Managemen Pribadi }\end{array}$ \\
\hline 1 & Menetapkan focus & Mendiagnosis informasi & Percaya diri \\
\hline 2 & Motivasi pendorong & Berpikir analitis & Manajemen stress \\
\hline 3 & Kerja kelompok & Berpikiran ke depan & Kridibilitas pribadi \\
\hline 4 & Pemberdayaan orang lain & Berpikiran konseptual & Fleksibel \\
\hline 5 & Mengelola perubahan & Berpikiran strategis & \\
\hline 6 & $\begin{array}{l}\text { Mengembangkan orang } \\
\text { lain }\end{array}$ & Keahlian teknik & \\
\hline 7 & Mengelola kinerja & Berinisiatif & \\
\hline 8 & Komunikasi efektif & Berorientasi enterprenur & \\
\hline 9 & Komunikasi lisan & Inovatif & \\
\hline 10 & Komunikasi tertulis & Berorientasi hasil & \\
\hline 11 & Komunikasi persuasive & Bekerja tuntas & \\
\hline 12 & Kesadaran interpersonal & Tepat dan cepat mengambil \\
& putusan & \\
\hline 13 & $\begin{array}{l}\text { Mempengaruhi } \\
\text { lain }\end{array}$ & & \\
\hline 14 & $\begin{array}{l}\text { Mengembangkan } \\
\text { hubungan kolaboratif }\end{array}$ & & \\
\hline 15 & $\begin{array}{l}\text { Berorientasi pada } \\
\text { pelanggan }\end{array}$ & & \\
\hline
\end{tabular}

Soft skills didefinisikan sebagai deskripsi kepribadian, sosial dan perilaku behaviorial. Soft skill merupakan persepsi individu yang menunjukkan kemampuan berkomunikasi dalam setiap konteks yang berbeda. Soft skills dibagi ke dalam tiga kelompok: kualitas personal, kemampuan interpersonal, dan keterampilan teknik dan pengetahuan. Soft skills bisa 
diajarkan melalui tiga cara: pertama, menunjukkan kesadaran akan pentingnya soft skill dan pembelajar bisa membuat evaluasi diri; kedua, menerapkan nilai-nilai soft skills ke dalam pembelajaran; ketiga, dilakukan menggunakan model peran. Soft skills sebagai kompetensi bisa dituangkan ke dalam enam area kompetensi, yaitu: pengetahuan akademik, keterampilan interpersonal dan komunikasi, keuletan belajar, sikap professional, belajar berbasis-praktik dan pengembangan, dan sistem-berbasis praktik (Wallace, Anderson \& McHugo, 2013).

Tabel 5. Soft Skills dan Hard skills

\begin{tabular}{lll}
\hline No & \multicolumn{1}{c}{ Soft-skills } & \multicolumn{1}{c}{ Hard-skills } \\
\hline 1 & Jujur & Lancar berbahasa Inggris tulis \& lisan \\
\hline 2 & keterampilandalam komunikasi & Bisa berbicara di depan umum \\
\hline 3 & Memiliki manajemen waktu & Memiliki sertifikat tertentu \\
\hline 4 & keterampilan bekerjasama & Memiliki pengelaman bidang tertentu \\
\hline 5 & bersikap empatik pada orang lain & Memiliki keterampilan bidang tertentu \\
\hline 6 & $\begin{array}{l}\text { konsisten,bertanggungjawab, memiliki } \\
\text { komitmen }\end{array}$ & Bisa menjelaskan suatu permasalahan \\
\hline 7 & Tahan dan ulet menghadapi cobaan & Menyelesaikan tugas tepat waktu \\
\hline 8 & Menguatamakan tugas & \\
\hline 9 & Percaya diri & \\
\hline 9 & Mampu mengendalikan diri & \\
\hline
\end{tabular}

Dikutip dari (Schulz, 2008:146-158)

Berdasarkan uraian di atas, penyesuaian KKNI ke dalam kurikulum di semua jenjang sudah menjadi kewajiban. Namun terdapat kerancuan yang berpotensi menjadikan konsep KKNI tidak tuntas seperti pelaksanaan KBK dan KTSP. Ketika konsep mulai tersosialisasi dan mulai bisa dilaksanakan, kebijakan sudah berubah dan aktivitas "terjual habis" pada kebijakan yang baru diluncurkan.

Dalam konteks ini peneliti melihat ada dua hal yang memungkinkan menjadi kendala lapangan. Pertama, penerapan kompetensi inti, kompetensi dasar, dan standard kompetensi dalam struktur silabus, akan tumpang tindih. Kompetensi inti nampak "dipaksakan" sebagai acuan setiap mata ajar. Kedua, penggunaan istilah learning outcomes, kompetensi, dan capaian pembelajaran, seperti diakui sendiri oleh pemerintah, berpotensi "membingungkan" guru dalam membuat "learning objectives". Ketiga, unsur-unsur dalam kompetensi inti sebenarnya terkandung di dalam soft skills yang secara aktual sudah terukur. Tanpa didasari pemahaman yang jelas mengenai metode dan proses pelaksanaannya, aspek ini berpotensi menjadikan guru salah arah dalam mengajar di kelas. Keempat, kompetensi inti memungkinkan ditafsirkan sebagai deskripsi jenjang kualifikasi yang dituangkan dalam Peraturan Presiden Nomor 8 Tahun 2012. Kompetensi inti dianggap sebagai deskripsi SKL dalam ukuran tertentu, sedangkan deskripsi jenjang kualifikasi menunjukkan uraian kemampuan lulusan yang harus dicapai. KKNI sebagai penciri khas Indonesia patut didukung, tetapi masih diperlukan penjabaran lebih rinci pada berbagai aspek dan memerlukan waktu yang cukup lama untuk bisa mantap dan diinternalisasi. 


\section{SIMPULAN}

Kehadiran KKNI sebagai rujukan program pendidikan di tingkat dasar sampai perguruan tinggi di Indonesia telah menuntut perubahan pada design kurikulum. Isu yang sekarang paling hangat ialah penyesuaian KBK ke dalam KBO. Penyesuaian pertama ialah perubahan visi dan misi menyepadakan dengan KKNI. Penyesuaian berikutnya ialah pencantuman KI dan KD. KKNI untuk tingkat dasar dan menengah sudah dirumuskan oleh pemerintah, tetapi untuk pegururuan tinggi dikembangkan sendiri. Dasar penyusunan kurikulum perguruan tinggi tetaplah KBK dan menggunakan kerangka perkuliahan seperti termaktub dalam SK Mendiknas No. 045/U/2002.

Secara teknis pengembangan kurikulum, beberapa istilah yang digunakan dalam KBO yang menyesuaikan dengan KKNI perlu dipertajam dengan merujuk pada kurikulum lain yang sudah menggunakan istilah tersebut secara matang. Artikel ini mencoba merujuk pada Kurikulum di Palm Beach State College Amerika, Quesn Marry University of London, dan Kurikulum di University of Tennessee Memphis Amerika. Hasil rujukan menunjukkan bahwa kerangka kualifikasi ialah kebijakan pemerintah untuk menetapkan kualifikasi tenaga kerja dan kualifikasi tersebut perlu diserap dalam kurikulum di sekolah dan perguruan tinggi. KI sama maknanya dengan core competency, yang merupakan daya tawar bagaimana suatu program akan berhasil dan digunakan di masyarakat. Untuk menguraikan core competency, diperlukan rumusan objectives, yang setara dengan SK dan KD. Dalam KI terdapat kompetensi beragama dan sosial. Kompetensi beragama tidak tercakup dalam bagian kompetensi inti untuk perusahaan. Kompetensi sosial dan managerial jelas tercakup dan keduanya merupakan bagian dari soft skills. Pemahaman terhadap pengembangan dan design kurikulum melalui analisis kebutuhan, proses KBK, dan perumusan learning outcomes dan objectives kiranya bisa menanamkan konsep secara lebih mantap sehingga pelaku pendidikan tidak "terjual habis" dengan trend baru, dan segera bisa mnemukan jati diri.

\section{DAFTAR PUSTAKA}

Arreola, R. 2013. Writing Learning Objectives. Memphis: University of Tennessee.

Auerbach, E.R. 1986. The Hidden Curriculum of Survival ESL. TESOL Quarterly, 9(3):475-495.

Depdiknas. 2010. Buku Pedoman Kerangka Kualifikasi Nasional Indonesia. Jakarta: Direktorat Jendral Pendidikan Tinggi.

Depdiknas. 2008. Pengembangan Kurikulum pada Pendidikan Kesetaraan. Jakarta: Balai Pengembangan Pendidikan Non-Formal dan Informal.

Depdiknas, 2003. Undang-Undang Nomor 20 Tahun 2003 tentang Sistem Pendidikan Nasional. Biro Hukum Depdiknas, Jakarta. (diunduh dari www.depdiknas.go.id)

Imroatus Solikhah. 2013. English for Academic Purposes Voices: A Survey on Practices and Challenges in the State Universities of Central Java, Indonesia. International Journal of Academic Rerearch, 5(4):121-125.

Imroatus Solikhah. 2014a. Buku Teks Bahasa Inggris Akademik Berbasis 
Kompetensi untuk Mahasiswa Jurusan Non-Bahasa Inggris (Penelitian dan Pengembangan di Universitas Negeri di Jawa Tengah dan DIY). Disertasi. Program Doktor Pendidikan Bahasa. Surakarta: FKIP Universitas Sebelas Maret.

Imroatus Solikhah. 2014b. English for Academic Purposes: A Competency-

Based Textbook for EFL Learners. Yogjakarta: Penerbit Imperium.

Lawrence. 2011. Textbook Evaluation: A Framework for Evaluating the

Fitness of the Hong Kong New Secondary School Curriculum. Master's Thesis. Hong Kong: Department of English, City University of Hing Kong.

Learning ManagementCorporation. 2013. Developing Clear Learning

Outcomes and Objectives. Available at: www.thelearningmanager.com

Palm Beach State College. 2013. Academic Management Manual: Outcomes

Assessment Workbook. Available at:

www.palmbeachstate.edu/academicservices/documents/sectionl.pdf.

Peraturan Presiden Nomor 8 Tahun 2012. Kerangka Kualifikasi Nasional

Indonesia. Jakarta: Sekretariat Negara.

Queen Mary University of London. 2013. Good Practice Guide on Writing Aims and Learning Outcomes. Available at: www.learninginstitute.qmul.ac.uk.

Richards, Jack. 2013. Currciulum Approaches in Language Teaching:

Forward, Central, and Backward Design. RELC Journal, 44(1):5-33.

Schulz, B. 2008. The Importance of Soft Skills: Education Beyond Academic

Knowledge. Journal of Language and Communication. June, 2008:146-154.

Wallace, R, Anderson J, McHugo J. 3013. Soft Skills Hard Skills: Element of

Teaching. Dakota: University of North Dakota. 
LINGUA, Vol. 12, No. 1, Maret 2015

p ISSN: 1979 9411; e ISSN: 2442 238X; Web: lingua.pusatbahasa.or.id Pusat Kajian Bahasa dan Budaya, Surakarta, Indonesia

Solikhah, Imroatus. 2015. KKNI dalam Kurikulum Berbasis Learning Outcomes. Lingua, 12(1): 1 22.

LAMPIRAN. Jenjang Kualifikasi Menurut Perpres No. 8 Tahun 2012

\begin{tabular}{|c|c|c|}
\hline No & Jenjang Kualifikasi & Uraian \\
\hline 1 & Umum & $\begin{array}{l}\text { a. Bertaqwa kepada Tuhan Yang Maha Esa } \\
\text { b. Memiliki moral, etika dan kepribadian yang baik } \\
\text { dalam menyelesaikan tugasnya } \\
\text { c. Berperan sebagai warga negara yang bangga dan } \\
\text { cinta tanah air serta mendukung perdamaian } \\
\text { dunia } \\
\text { d. Mampu bekerja sama dan memiliki kepekaan } \\
\text { sosial dan kepedulian yang tinggi terhadap } \\
\text { masyarakat dan lingkungannya } \\
\text { e. Menghargai keanekaragaman budaya, } \\
\text { pandangan, kepercayaan dan agama serta } \\
\text { pendapat umum/temuan original orang lain } \\
\text { f. Menjunjung tinggi penegakan hukum serta } \\
\text { memiliki semangat untuk mendahulukan } \\
\text { kepentingan bangsa serta masyarakat luas }\end{array}$ \\
\hline 2 & 1 & $\begin{array}{l}\text { 1. Mampu melaksanakan tugas sederhana terbatas, } \\
\text { bersifat rutin, dengan menggunakan alat, aturan, } \\
\text { dan proses yang ditetapkan, serta di bawah } \\
\text { bimbingan pengawasan dan tanggungjawab } \\
\text { atasannya. } \\
\text { 2. Memiliki pengetahuan faktual. } \\
\text { 3. Bertanggungjawab atas pekerjaan sendiri dan } \\
\text { tidak bertanggungjawab atas pekerjaan orang } \\
\text { lain. }\end{array}$ \\
\hline 3 & 2 & $\begin{array}{l}\text { 1. Mampu melaksanakan suatu tugas spesifik, } \\
\text { dengan menggunakan alat, informasi, dan } \\
\text { prosedur kerja yang lazim dilakukan, serta } \\
\text { menunjukkan kinerja dengan mutu yang } \\
\text { terukur di bawah pengawasan langsung } \\
\text { atasannya. } \\
\text { Memiliki pengetahuan operasional dasar dan } \\
\text { pengetahuan faktual bidang kerja yang } \\
\text { spesifik sehingga mampu memilih } \\
\text { penyelesaian yang tersedia terhadap masalah } \\
\text { yang lazim timbul. } \\
\text { Bertanggungjawab terhadap pekerjaan sendiri } \\
\text { dan dapat diberi tanggungjawab membimbing } \\
\text { orang lain. }\end{array}$ \\
\hline 4 & 3 & $\begin{array}{l}\text { 1. Mampu melaksanakan serangkaian tugas } \\
\text { spesifik dengan menerjamahkan informasi dan } \\
\text { menggunakan alat, berdasarkan sejumlah } \\
\text { pilihan prosedur kerja, serta mampu }\end{array}$ \\
\hline
\end{tabular}


LINGUA, Vol. 12, No. 1, Maret 2015

p ISSN: 1979 9411; e ISSN: 2442 238X; Web: lingua.pusatbahasa.or.id

Pusat Kajian Bahasa dan Budaya, Surakarta, Indonesia

Solikhah, Imroatus. 2015. KKNI dalam Kurikulum Berbasis Learning Outcomes. Lingua, 12(1): 1 22.

\begin{tabular}{|c|c|c|}
\hline & & $\begin{array}{l}\text { menunjukkan kinerja dengan mutu dan kuantitas } \\
\text { yang terukur, yang sebagian merupakan hasil } \\
\text { kerja sendiri dengan pengawasan tidak } \\
\text { langsung. } \\
\text { 2. Memiliki pengetahuan operasional yang } \\
\text { lengkap, prinsip-prinsip serta konsep umum } \\
\text { yang terkait dengan fakta bidang keahlian } \\
\text { tertentu, sehingga mampu menyelesaikan } \\
\text { berbagai masalah yang lazim dengan metode } \\
\text { yang sesuai. } \\
\text { 3. Mampu bekerja sama dan melakukan } \\
\text { komunikasi dalam lingkup kerjanya. } \\
\text { 4. Bertanggungjawab pada pekerjaan sendiri dan } \\
\text { dapat diberi tanggung jawab atas kuantitas dan } \\
\text { mutu hasil kerja orang lain. }\end{array}$ \\
\hline 5 & 4 & $\begin{array}{l}\text { 1. Mampu menyelesaikan tugas berlingkup luas } \\
\text { dan kasus spesifik dengan menganalisis } \\
\text { informasi secara terbatas, memilih metode yang } \\
\text { sesuai dari berbagai pilihan yang baku, serta } \\
\text { mampu menunjukkan kinerja dengan mutu dan } \\
\text { kuantitas yang terukur. } \\
\text { 2. Menguasai beberapa prinsip dasar bidang } \\
\text { keahlian tertentu dan mampu menyelaraskan } \\
\text { dengan permasalahan faktual di bidang } \\
\text { kerjanya. } \\
\text { 3ampu bekerja sama dan melakukan } \\
\text { komunikasi, menyusun laporan tertulis dalam } \\
\text { lingkup tugas dan memiliki insiatif. } \\
\text { 4. Bertanggungjawab pada pekerjaan sendiri dan } \\
\text { dapat diberi tanggungjawab atas hasil kerja } \\
\text { orang lain. }\end{array}$ \\
\hline 6 & 5 & $\begin{array}{l}\text { 1. Mampu menyelesaikan pekerjaan berlingkup } \\
\text { luas, memilih metode yang sesuai dari beragam } \\
\text { pilihan yang sudah maupun belum baku } \\
\text { dengan menganalisis data, serta mampu } \\
\text { menunjukkan dengan mutu dan kuantitas yang } \\
\text { terukur. } \\
\text { 2. Menguasai konsep teoritis bidang pengetahuan } \\
\text { tertentu secara umum serta mampu } \\
\text { memformulasikan penyelesaian masalah } \\
\text { prosedural. } \\
\text { 3ampu mengelola kelompok kerja dan } \\
\text { menyusun laporan tertulis secara } \\
\text { komprehensif. } \\
\text { Bertanggungjawab atas pekerjaan sendiri dan } \\
\text { dapat diberi tanggung jawab atas pencapaian } \\
\text { hasil kerja kelompok. }\end{array}$ \\
\hline
\end{tabular}


LINGUA, Vol. 12, No. 1, Maret 2015

p ISSN: 1979 9411; e ISSN: 2442 238X; Web: lingua.pusatbahasa.or.id Pusat Kajian Bahasa dan Budaya, Surakarta, Indonesia

Solikhah, Imroatus. 2015. KKNI dalam Kurikulum Berbasis Learning Outcomes. Lingua, 12(1): 1 22.

\begin{tabular}{|c|c|c|}
\hline 7 & 6 & $\begin{array}{l}\text { 1. Mampu mengaplikasikan bidang keahliannya } \\
\text { dan memanfaatkan ilmu pengetahuan, } \\
\text { teknologi, dan/atau seni pada bidangnya dalam } \\
\text { penyelesaian masalah serta mampu beradaptasi } \\
\text { terhadap situasi yang dihadapi. } \\
\text { 2. Menguasai konseo teoritis bidang pengetahuan } \\
\text { tertentu secara umum dan konsep teoritis } \\
\text { bagian khusus dalam bidang pengetahuan } \\
\text { tersebut secara mendalam serta mampu } \\
\text { memformulasikan penyelesaian masalah } \\
\text { prosedural. } \\
\text { Mampu mengambil keputusan yang tepat } \\
\text { berdasarkan analisis informasi dan data, dan } \\
\text { mampu memberikan petunjuk dalam memilih } \\
\text { berbagai alternatif solusi secara mandiri dan } \\
\text { kelompok. } \\
\text { Bertanggung jawab pada pekerjaan sendiri dan } \\
\text { dapat diberi tanggung jawab atas pencapaian } \\
\text { hasil kerja organisasi. }\end{array}$ \\
\hline 8 & 7 & $\begin{array}{l}\text { 1. Mampu merencanakan dan mengelola } \\
\text { sumberdaya di bawah tanggungjawabnya, dan } \\
\text { mengevaluasi secara komprehensif kerjanya } \\
\text { dengan memanfaatkan ilmu pengetahuan, } \\
\text { teknologi, dan/atau seni untuk menghasilkan } \\
\text { langkah-langkah pengembangan strategis } \\
\text { organisasi. } \\
\text { 2. Mampu memecahkan permasalahan ilmu } \\
\text { pengetahuan, teknologi, dan/atau seni di dalam } \\
\text { bidang keilmuannya melalui pendekatan } \\
\text { multidisipliner. } \\
\text { 3. Mampu melakukan riset dan mengambil } \\
\text { keputusan strategis dengan akuntabilitas dan } \\
\text { tanggungjawab penuh atas semua aspek yang } \\
\text { berada di bawah tanggungjawab bidang } \\
\text { keahliannya. }\end{array}$ \\
\hline
\end{tabular}


LINGUA, Vol. 12, No. 1, Maret 2015

p ISSN: 1979 9411; e ISSN: 2442 238X; Web: lingua.pusatbahasa.or.id

Pusat Kajian Bahasa dan Budaya, Surakarta, Indonesia

Solikhah, Imroatus. 2015. KKNI dalam Kurikulum Berbasis Learning Outcomes. Lingua, 12(1): 1 22.

Lampiran. Deskripsi Jenjang Kualifikasi Menurut Perpres No. 8 Tahun 2012

\begin{tabular}{|c|c|c|}
\hline No & Jenjang Kualifikasi & Uraian \\
\hline 9 & 8 & $\begin{array}{l}\text { 1. Mampu mengembangkan pengetahuan, teknologi, } \\
\text { dan/atau seni di dalam bidang keilmuannya atau } \\
\text { praktik profesionalnya melalui riset hingga } \\
\text { menghasilkan karya inovatif dan teruji. } \\
\text { 2. Mampu memecahkan masalah permasalahan ilmu } \\
\text { pengetahuan, teknologi dan/atau seni dalam bidang } \\
\text { keilmuannya melalui pendekatan inter atau } \\
\text { multidisipliner. } \\
\text { 3. Mampu mengelola riset dan pengembangan yang } \\
\text { bermanfaat bagi masyarakat dan keilmuan, serta } \\
\text { mampu mendapat pengakuan nasional dan } \\
\text { internasional. }\end{array}$ \\
\hline 10 & 9 & $\begin{array}{l}\text { 1. Mampu mengembangkan pengetahuan, teknologi } \\
\text { dan/atau seni baru di bidang keilmuannya atau } \\
\text { praktik profesionalnya melalui riset hingga } \\
\text { menghasilkan karya kreatif, oroginal dan teruji. } \\
\text { 2. Mampu memecahkan permasalahan ilmu } \\
\text { pengetahuan, teknologi dan/atau seni di bidang } \\
\text { keilmuannya melalui pendekatan inter, multi dan } \\
\text { transdisipliner. } \\
\text { 3. Mampu mengelola, memimpin dan } \\
\text { mengembangkan riset dan mengembangkan riset } \\
\text { dan pengembangan yang bermanfaat bagi } \\
\text { kemaslahatan umat manusia, serta mampu } \\
\text { mendapat pengakuan nasional dan internasional. }\end{array}$ \\
\hline
\end{tabular}


LINGUA, Vol. 12, No. 1, Maret 2015

p ISSN: 1979 9411; e ISSN: 2442 238X; Web: lingua.pusatbahasa.or.id

Pusat Kajian Bahasa dan Budaya, Surakarta, Indonesia

Solikhah, Imroatus. 2015. KKNI dalam Kurikulum Berbasis Learning Outcomes.

Lingua, 12(1): 1 22. 